\section{Intravenous ketorolac vs diclofenac for analgesia after maxillofacial surgery}

Pekka Tarkkila MD PhD, Marjatta Tuominen MD PhD Per H. Rosenberg MD PhD
Purpose: To compare the efficacy of the non-steroidal antiinflammatory drugs (NSAID), ketorolac and diclofenac in prevention of pain after maxillofacial surgery.

Methods: Sixty ASA I-II patients (30 in each group) received randomly, and double blindly either ketorolac $0.4 \mathrm{mg} \cdot \mathrm{kg}^{-1}$ or diclofenac $1.0 \mathrm{mg} \cdot \mathrm{kg}^{-1}$ iv after general anaesthesia induction, before surgical incision. In the ketorolac group, the same dose was repeated iv three times at six hour intervals. The diclofenac group patients received diclofenac $1.0 \mathrm{mg} \cdot \mathrm{kg}^{-1}$ after $12 \mathrm{hr}$ iv. Rescue analgesic medication consisting of oxycodone $0.03 \mathrm{mg} \cdot \mathrm{kg}^{-l} \mathrm{iv}$, was administered by a patient controlled analgesia apparatus.

Results: Two patients in the ketorolac and three patients in the diclofenac group did not need oxycodone during the study period. On average, 12 and 11 doses of oxycodone were needed in the ketorolac and the diclofenac groups, respectively (NS). Side-effects were similar in both groups. All patients except one were satisfied with the pain therapy.

Conclusion: Parenteral ketorolac $\left(0.4 \mathrm{mg} \cdot \mathrm{kg}^{-1}\right.$ four times in $24 \mathrm{hr}$ ) and diclofenac $\left(1 \mathrm{mg} \cdot \mathrm{kg}^{-1}\right.$ twice in $24 \mathrm{hr}$ ) were similar, but insufficient alone, for analgesia after maxillofacial surgery.

Objectif: Comparer l'efficacité des anti-inflammatoires non stéroïdiens kétotolac et diclofénac pour la prévention de la douleur en chirurgie maxillofaciale.

Méthode: Soixante patients ASA I et II (30 dans chaque groupe), randomisés et en double aveugle, ont reçu soit kétorolac $0,4 \mathrm{mg} \cdot \mathrm{kg}^{-1}$ soit diclofénac $1,0 \mathrm{mg} \cdot \mathrm{kg}^{-1}$ après l'in-

\section{Key words}

ANESTHETIC TECHNIQUES: general;

PAIN: postoperative, PCA;

DRUGS: ketorolac, diclofenac.

From the Department of Anaesthesia, 4th Dept of Surgery, University of Helsinki, Finland.

Address correspondence to: Dr. Pekka Tarkkila, Department of Anaesthesia, 4th Dept of Surgery, University of Helsinki, Kasarmikatu 11-13, Fin-00130 Helsinki, Finland.

Fax: Int-358-0-654294.

Accepted for publication 5th October, 1995. duction de l'anesthésie et avant l'incision. Dans le groupe kétorolac, la même dose intraveineuse a été répétée trois fois avec un intervalle de six heures. Le groupe diclofénac a reçu le diclofénac $1,0 \mathrm{mg} \cdot \mathrm{kg}^{-1}$ iv après $12 \mathrm{~h}$. L'oxycodone 0,03 $\mathrm{mg} \cdot \mathrm{kg}^{-1}$ iv administré à l'aide d'un système autocontrôlé servait d'analgésique de sauvetage.

Résultat: Deux patients du groupe kétorolac et trois patients du groupe diclofénac n'ont pas eu besoin d'oxycodone pendant l'étude. En moyenne, 12 et 11 doses d'oxycodone ont été nécessaires respectivement dans le groupe kétorolac et dans le groupe diclofénac (NS). Les effets secondaires ont été lés mêmes dans les deux groupes. Tous les patients excepté un ont été satisfaits de leur analgésie.

Conclusion: Le kétorolac $\left(0,4 \mathrm{mg} \cdot \mathrm{kg}^{-1}\right.$ quatre fois en $\left.24 \mathrm{~h}\right)$ et le diclofénac ( $1 \mathrm{mg} \cdot \mathrm{kg}^{-1}$ deux fois en $24 \mathrm{~h}$ ) ont eu le même effet, mais à eux seuls ont été insuffisants pour procurer l'analgésie après une chirurgie maxillofaciale.

Nonsteroidal antiinflammatory drugs (NSAID) have been found to be effective in eliminating pain after various types of surgery. ${ }^{1}$ Although the mechanism of analgesic action i.e., inhibition of prostaglandin synthesis (cyclo-oxygenase activity) is the same for all presently used NSAIDs, the analgesic efficacy relative to side-effects may vary from agent to agent. ${ }^{2}$ Recently, we have showed that pain after maxillofacial surgery was more effectively reduced by parenterally administered diclofenac than by parenteral ketoprofen. ${ }^{3}$ Also, diclofenac has been found to have an opioid-sparing effect after several other types of surgery. ${ }^{4-6}$ The most recent parenteral NSAID for the control of postoperative pain is ketorolac. ${ }^{7,8}$ The analgesic potency of ketorolac $30 \mathrm{mg}$ im has been shown to be comparable with morphine $10-12 \mathrm{mg} \mathrm{im}^{8,9}$

Comparative studies between the analgesic efficacy of ketorolac and diclofenac are rare. In cancer pain, ketorolac suppositories $(30 \mathrm{mg})$ were more efficacious than diclofenac $(100 \mathrm{mg})$, but only for the first $12 \mathrm{hr}$ of treatment. ${ }^{10}$ Also, following arthroscopy of the knee joint, ketorolac provided better postoperative analgesia than diclofenac. ${ }^{11}$ On the other hand, after removal of 
impacted mandibular third molar teeth im ketorolac and diclofenac provided a similar degree of pain relief. ${ }^{12}$ Since the type of surgery may influence the efficacy of individual NSAIDs on postoperative pain, ${ }^{2}$ we found it worthwhile to compare the postoperative analgesic efficacy of ketorolac and diclofenac in a relatively homogeneous population, i.e., patients undergoing maxillofacial surgery.

\section{Methods}

After obtaining informed consent, 60 ASA I-II patients scheduled for maxillofacial surgery were randomly assigned to receive either ketorolac or diclofenac according to a double-blind protocol design approved by the Ethics Committee of the hospital. Patients with a history of allergic reactions to NSAIDs, bronchial asthma, gastrointestinal ulceration or bleeding disorders were excluded from the study.

Dexamethasone, $4 \mathrm{mg}$ iv was given to osteotomy patients three times (with the premedication, during surgery and in the first postoperative night) to reduce swelling and postoperative inflammation. Premedication consisted of diazepam $0.15 \mathrm{mg} \cdot \mathrm{kg}^{-1} \mathrm{po}$, and oxycodone $0.14 \mathrm{mg} \cdot \mathrm{kg}^{-1} \mathrm{im}$ about $45 \mathrm{~min}$ before induction of anaesthesia. After $0.2 \mathrm{mg}$ glycopyrrolate, anaesthesia was induced with thiopentone about $5 \mathrm{mg} \cdot \mathrm{kg}^{-1}$ iv and maintained with enflurane in $\mathrm{O}_{2} / \mathrm{N}_{2} \mathrm{O}$ (30/70\%). Tracheal intubation was facilitated with succinylcholine $1-1.5 \mathrm{mg} \cdot \mathrm{kg}^{-1}$ and muscle relaxation was maintained with alcuronium. All patients received small incremental doses of fentanyl for analgesia.

The ECG, $\mathrm{SpO}_{2}, \mathrm{PETCO}_{2}$, noninvasive arterial blood pressure (oscillotonometry) and heart rate were monitored during the anaesthesia. On the first postoperative day, the serum creatinine concentration was measured in the hospital laboratory.

\section{Study drugs}

After induction of general anaesthesia, before surgical incision, the patients received iv either ketorolac tromethamine (Toradol ${ }^{\circledR}$, Syntex, Sweden) $0.4 \mathrm{mg} \cdot \mathrm{kg}^{-1}$ in $100 \mathrm{ml} 0.9 \% \mathrm{NaCl}$ or diclofenac sodium (Voltaren ${ }^{\circledR}$, Ciba Geigy, Basel, Switzerland) $1.0 \mathrm{mg} \cdot \mathrm{kg}^{-1}$ in $100 \mathrm{ml}$ $0.9 \% \mathrm{NaCl}$. In the ketorolac group, the same iv dose was repeated three times at six hour intervals.

In the diclofenac group the patients received placebo $(0.9 \% \mathrm{NaCl})$ after six hours, diclofenac $1.0 \mathrm{mg} \cdot \mathrm{kg}^{-1}$ after $12 \mathrm{hr}$ and finally placebo $i v$ after $18 \mathrm{hr}$. The daily dose of diclofenac was divided into two equal doses. Such an administration interval has been found adequate by Hodsman and coworkers. ${ }^{5}$ No other NSAID medication was allowed during the study period.

Rescue analgesic medication consisting of oxycodone
TABLE I Patients' characteristics and types of surgery (mean \pm SD or number of patients).

\begin{tabular}{lcc}
\hline & Ketorolac group & Diclofenac group \\
\hline Age (yr) & $30 \pm 9$ & $33 \pm 11$ \\
Height (cm) & $172 \pm 8$ & $173 \pm 8$ \\
Weight (kg) & $68 \pm 13$ & $69 \pm 15$ \\
Sex (female/male) & $18 / 12$ & $17 / 13$ \\
Type of operation & \multicolumn{2}{|l}{} \\
- osteotomy & 20 & 19 \\
- other bone operation & 6 & 5 \\
- removal of plates & 3 & 4 \\
- soft tissue operation & 1 & 2 \\
Duration of operation (min) & $161 \pm 72$ & $127 \pm 63$ \\
Blood loss (ml) & $250 \pm 320$ & $181 \pm 250$ \\
Fentanyl during anaesthesia (mg) & $0.5 \pm 0.2$ & $0.4 \pm 0.2$ \\
\hline
\end{tabular}

$0.03 \mathrm{mg} \cdot \mathrm{kg}^{-1} i v$ (four-hour maximum dose $0.4 \mathrm{mg} \cdot \mathrm{kg}^{-1}$ and lock-out time five minutes) was administered by a patient controlled analgesia (PCA) apparatus (Lifecare ${ }^{\circledR}$, Abbott, USA). The use of the PCA-device was explained to each patient during the preoperative visit. The patients were advised to demand analgesic delivery so often that they would be painfree. The number of doses and administration attempts and exact time of administration were recorded.

All patients were visited by one of the investigators on the first postoperative day, approximately $24 \mathrm{hr}$ after anaesthesia. Subjective side effects, recorded at predetermined intervals (i.e., during the stay in the recovery room, on the ward until 9 p.m., and on the ward from 9 p.m. to the 24-hr interview) were registered. The patients' opinions (graded good, fair or poor) regarding the quality of analgesia and the system drug delivery were also recorded.

\section{Statistics}

The results are expressed as mean ( $\pm \mathrm{SD}$ ) (or range). Student's t test, Mann-Whitney test, chi-square test and Fisher's exact tests were used as appropriate. A value of $P<0.05$ was considered statistically significant.

\section{Results}

The groups were comparable with respect to demographic data and type of maxillofacial surgery (Table I). There was no difference in the mean amount of perioperative fentanyl between the groups (Table I) and the amount of intraoperative fentanyl did not correlate with postoperative opioid demands. The number of patients receiving perioperative dexamethasone (osteotomies) was comparable in both groups (21 vs 19 patients). The recovery period was uneventful in all patients.

Two patients in the ketorolac $(7 \%)$ and three patients in the diclofenac group $(10 \%)$ did not need any 
TABLE II Mean number and range of self-administered oxycodone doses (average dose in $\mathrm{mg}$ ) and demands during $24 \mathrm{hr}$ study period.

\begin{tabular}{lll}
\hline Time interval & Ketorolac group & Diclofenac group \\
\hline $0-6 \mathrm{hr}$ & $2.2(4.4 \mathrm{mg})$ & $3.6(7.2 \mathrm{mg})$ \\
& $(0-8)$ & $(0-14)$ \\
$6-12 \mathrm{hr}$ & $3.8(7.6 \mathrm{mg})$ & $3.2(6.4 \mathrm{mg})$ \\
& $(0-11)$ & $(0-10)$ \\
$12-18 \mathrm{hr}$ & $2.8(5.6 \mathrm{mg})$ & $2.1(4.2 \mathrm{mg})$ \\
& $(0-9)$ & $(0-9)$ \\
$18-24 \mathrm{hr}$ & $3.0(6.0 \mathrm{mg})$ & $2.2(4.4 \mathrm{mg})$ \\
& $(0-9)$ & $(0-10)$ \\
Total & $12(24 \mathrm{mg})$ & $11(22 \mathrm{mg})$ \\
& $(0-27)$ & $(0-27)$
\end{tabular}

Number of additional demands

during lock-out $\quad 1.1(0-13) \quad 1.0(0-7)$

PCA-delivered oxycodone during the trial. All these patients except one in the diclofenac group belonged to the minor surgery group. A similar number of oxycodone doses were needed in both groups (Table II). With osteotomy patients, on average, $14.4(29 \mathrm{mg})$ and $13.6(27 \mathrm{mg})$ doses of oxycodone were needed in the ketorolac and the diclofenac groups, respectively (NS). In minor operations the need for oxycodone was also similar in both groups (two and three doses, on average, in the ketorolac and diclofenac groups, respectively). There were no intergroup or intragroup differences in the number of opioid doses between the six-hour observation periods (Table II).

In one patient in the ketorolac group further NSAID therapy was interrupted four hours after the second dose, and one hour after penicillin iv due to urticaria. Three patients in the diclofenac group and two in the ketorolac group experienced local venous pain during administration. The occurrence of side-effects such as, pruritus, dizziness, sleepiness and urinary problems, were similar in both groups (Table III). The postoperative serum creatinine concentrations were normal in all patients.

All patients, except one in the ketorolac group, rated their opinion of the pain therapy as good. The particular patient who rated the therapy as fair, announced that he had not received enough analgesic in spite of the properly functioning PCA-device.

\section{Discussion}

In the present study, intravenous ketorolac and diclofenac proved to be equal in pain prevention after maxillofacial surgery. Numerous mild side-effects were noted (Table III). Most of them were of minor clinical importance, and appeared in comparable frequency in both study groups. The high frequency of sleepiness
TABLE III Postoperative side-effects and complaints during the study period (number of patients).

\begin{tabular}{lrc}
\hline & Ketorolac group & Diclofenac group \\
\hline Nausea & 11 & 8 \\
Vomiting & 7 & 3 \\
Dizziness & 25 & 28 \\
Sleepiness & 25 & 25 \\
Pruritus & 5 & 5 \\
Irritation at venous infusion site & 2 & 3 \\
Micturition difficulties & 3 & 6 \\
Urinary bladder catheterisation & 3 & 2 \\
\hline
\end{tabular}

(83\%) among the study patients is probably the result of central nervous effects of the NSAIDs, ${ }^{13,14}$ and residual sedative effects of anaesthesia and the sedative effect of the concomitantly administered opioid. ${ }^{15}$ One patient in the ketorolac group, without a history of allergy or adverse drug reactions, suffered from urticaria about four hr after the second ketorolac dose. We were unable to establish with certainty the cause of this reaction, but temporally it was more closely associated with the penicillin infusion than with the ketorolac infusion.

Usually, in such studies, pain scores are used to differentiate between the potency of the drug under study compared with placebo which is used in the control group. The ethics of subjecting one group of patients to more pain than another is questionable. We considered the use of placebo infusion unnecessary, as an opioid-sparing effect of diclofenac compared with placebo after similar surgery in a similar category of patients had been shown in a recent report from our department. ${ }^{3}$ Various methods for the measurement of pain (verbal scores, visual analogue scale (VAS) etc) are available for the assessment of pain relief postoperatively. Scoring of pain on the visual analogue scale is probably the most often utilized method. However, with the use of a PCA-device the pain scores remain low if the use of the device has been taught and it is correctly operated. We advised our patients to deliver sufficient opioid to remain painfree. Therefore, one would not expect differences in VAS scores with this method in spite of the fact that some patients wish to avoid complete PCA-assisted painlessness in order not to become too dizzy or sedated. ${ }^{16}$ Patient acceptability of the PCA-system and the level of preoperative anxiety should probably also be considered when such devices are used in pain studies. ${ }^{17}$ Clinically, however, the PCA-system was quite successful as all but one of the patients reported that they were satisfied with the pain therapy. The number of opioid doses and demands in a PCA-system is an objective method for the assessment of the efficacy of postoperative pain therapy. ${ }^{18}$ 
The possible role of concomitantly administered dexamethasone on postoperative analgesia ${ }^{19}$ cannot be assessed from the present results. Dexamethasone is routinely used to reduce swelling in various types of maxillofacial surgery which involve bone trauma (e.g., sagittal osteotomies).

The dosing intervals of the NSAIDs were chosen according to current recommendations. The pharmacokinetics of ketorolac ${ }^{20}$ (e.g., elimination half-life is 5.1 hr) warrants the use of four doses during $24 \mathrm{hr}$. In spite of its short plasma elimination half-life $(1.1 \mathrm{hr}),{ }^{20}$ diclofenac divided into two doses over $24 \mathrm{hr}$ was similar regarding the overall 24-hr pain therapy. Even when the different six-hour intervals were examined and compared, e.g., the interval 6-12 hr and 18-24 hr when only ketorolac had been given, no differences in opioid consumption could be detected. The long therapeutic effect of diclofenac may have several reasons. Diclofenac is an extremely potent cyclo-oxygenase inhibitor ${ }^{21}$ and is known to accumulate in inflamed tissue where its concentrations are maintained much higher than in plasma for many hours. ${ }^{22}$ It also has active metabolites that act as analgesics. ${ }^{23}$ The clinical benefit of higher doses in postoperative pain would be questionable because of the risk of adverse effects on the kidneys. ${ }^{24}$ The NSAIDs can cause impairment of glomerular filtration, acute renal failure, oedema, interstitial nephritis, papillary necrosis, chronic renal failure and hyperkalaemia. ${ }^{25}$ The chronic use of NSAIDs is associated with increased risk for chronic renal disease. ${ }^{26}$ Our patients can be considered low-risk patients for renal complications as they were young and free from preoperative renal problems. According to postoperative serum creatinine values and clinical observation no adverse effect of NSAIDs on renal function was detected in this study. Micturition difficulties (inability to pass urine) occurred in both NSAID-groups at a similar frequency $(20-26 \%)$ as in the NSAID-groups (diclofenac and ketoprofen) of our previous study. ${ }^{3}$ There were no clinical signs of haemostatic disturbances such as increased postoperative bleeding or development of haematomas in our patients. This is in agreement with earlier studies. ${ }^{5,19}$

We conclude that parenteral ketorolac and diclofenac in the doses used were similar, for analgesia after maxillofacial surgery. In the majority of patients, opioid was also necessary. It may not be advisable to increase the dosage of these NSAIDs due to risk of renal and other complications. Instead, analgesics with other modes and sites of action should be combined, as needed, with NSAIDs for good postoperative pain control.

\section{References}

1 Souter AJ, Fredman B, White PF. Controversies in the perioperative use of nonsteroidal antiiflammatory drugs. Anesth Analg 1994; 79: 1178-90.

2 Moote C. Efficacy of nonsteroidal anti-inflammatory drugs in the management of postoperative pain. Drugs 1992; 44 (suppl.5): 14-30.

3 Niemi L, Tuominen $M$, Pitkanen $M$, Rosenberg $P H$. Comparison of parenteral diclofenac and ketoprofen for postoperative pain relief after maxillofacial surgery. Acta Anaesthesiol Scand 1995; 39: 96-9.

4 Hodsman NBA, Burns J, Blyth A, Kenny GNC, McArdle $C D$, Rotman $H$. The morphine sparing effects of diclofenac sodium following abdominal surgery. Anaesthesia 1987; 42: 1005-8.

5 Lindgren $U$, Djupsö $H$. Diclofenac for pain after hip surgery. Acta Orthop Scand 1985; 56: 28-31.

6 Nuutinen LS, Wuolijoki E, Pentikäinen IT. Diclofenac and oxycodone in treatment of postoperative pain: a doubleblind trial. Acta Anaesthesiol Scand 1986; 30: 620-4.

7 Yee JP, Koshiver JE, Allbon C, Brown CR. Comparison of intramuscular ketorolac tromethamine and morphine sulfate for analgesia of pain after major surgery. Pharmacotherapy 1986; 6: 253-61.

8 Rice ASC, Lloyd J, Miller CG, Bullingham RE, O'Sullivan $G M$. A double-blind study of the speed of onset of analgesia following intramuscular administration of ketorolac tromethamine in comparison to intramuscular morphine and placebo. Anaesthesia 1991; 46: 541-4.

9 O'Hara DA, Fragen RJ, Kinzer M, Pemberton D. Ketorolac tromethamine as compared with morphine sulfate for the treatment of postoperative pain. Clin Pharmacol Ther 1987; 41: 556-61.

10 Wool C, Prandoni P, Polistena P, Ruol A. Ketorolac suppositories in the treatment of neoplastic pain: a randomized clinical trial versus diclofenac. Current Therapeutic Research 1991; 49: 854-61.

11 Morrow BC, Bunting $H$, Milligan KR. A comparison of diclofenac and ketorolac for postoperative analgesia following day-case arthroscopy of the knee joint. Anaesthesia 1993; 48: 585-7.

12 Walton GM, Rood JP, Snowdon AT, Rickwood D. Ketorolac and diclofenac for postoperative pain relief following oral surgery. Br J Oral Maxillofac Surg 1993; 31: 158-60.

13 Rorarius M, Miralles J, Baer GA, Palomäki E. Diclofenac versus indomethacin given as intravenous infusions: their effect on haemodynamics and bleeding time, and side effects in healthy subjects. Annals of Clinical Research 1985; 17: 306-9.

14 MacDonald FC, Gough KJ, Nicoll RAG, Dow RJ. Psychomotor effects of ketorolac in comparison with buprenorphine and diclofenac. Br J Clin Pharmacol 1989; 27: 453-9.

15 Schulze S, Roikjaer O, Hasselstrøm PL, Jensen NH, Kehlet 
$H$. Epidural bupivacaine and morphine plus systemic indomethacin eliminates pain but not systemic response and convalescence after cholecystectomy. Surgery 1988 ; 103: 321-7.

16 Lehmann $K A$. Intravenous patient-controlled analgesia: postoperative pain management and research, $I n$ : Chrubasic J, Cousins M, Martin E (Eds.). Advances in Pain Therapy II. Berlin Heidelberg: Springer-Verlag, 1993: 65-93.

17 Thomas V, Heath M, Rose D, Flory P. Psychological characteristics and the effectiveness of patient-controlled analgesia. Br J Anaesth 1995; 74: 271-6.

18 Varrassi G, Panella L, Piroli A. et al. The effects of perioperative ketorolac infusion on postoperative pain and endocrine-metabolic response. Anesth Analg 1994; 78 : 514-9.

19 Weber CR, Griffin JM. Evaluation of dexamethasone for reducing postoperative edema and inflammatory response after orthognathic surgery. J Oral Maxillofac Surg 1994; 52: 35-9.

20 Mather $L E$. Do the pharmacodynamics of the nonsteroidal antiinflammatory drugs suggest a role in the management of postoperative pain? Drugs 1992; 44 (suppl 5): 1-13.

$21 K u E C$, Wasvary JM, Cash WD. Diclofenac sodium (GP 45840, Voltaren). A potent inhibitor of prostaglandin synthetase. Biochem Pharmacol 1975; 24: 641-3.

22 Fowler PD, Shadforth MF, Crook PR, John VA. Plasma and synovial fluid concentrations of diclofenac sodium and its major hydroxylated metabolites during long-term treatment of rheumatoid arthritis. Eur J Clin Pharmacol 1983; 25: 389-94.

23 Menassé R, Hedwall PR, Kraetz J, et al. Pharmacological properties of diclofenac sodium and its metabolites. Scand J Rheumatol 1978; 22 (suppl): 5-16.

24 Clive DM, Stoff JS. Renal syndromes associated with nonsteroidal antiinflammatory drugs. N Engl J Med 1984; 310: 563-72.

25 Lifschitz $M D$. Prostaglandins and renal blood flow: in vivo studies. Kidney Int 1981; 19: 781-5.

26 Sandler DP, Burr FR, Weinberg CR. Nonsteroidal anti-inflammatory drugs and the risk for chronic renal disease. Ann Int Med 1991; 115: 165-72. 